\title{
四 \\ CSR and Performance of Family Businesses: A Systematic Review
}

\author{
Pintian Lv' ${ }^{1}$, Yongqiang $\mathrm{Li}^{2}$ and Debi Mitra ${ }^{3}$
}

\begin{abstract}
There have been numerous studies on the relationship between CSR and performance of family businesses. However, academia have yet to come to a consensus regarding the sign and size of the relationship. Neither was there any consistent evidence on the boundary conditions for the relationship between CSR and performance in family businesses. Based on a review of Agency Theory, Stakeholder Theory, Stewardship Theory, Utilitarian Theory and Social Emotional Wealth Theory, this paper addresses the aforementioned research gap based on a systematic review. The study synthesised the literature on performance which is measured in three aspects by the existing literature, namely financial performance, social performance, and innovation. Moreover, the study assessed the empirical literature on the relationship between CSR and the aforementioned three performance measures. The study contributes to the literature by establishing the conceptual foundation for future empirical research.
\end{abstract}

JEL classification: Q56

Keywords: CSR, family business, empirical research

\footnotetext{
${ }^{1}$ PhD Candidate, Shandong University, Jinan, China; email: 243400730@qq.com

${ }^{2}$ Senior Lecturer, Victoria University, Melbourne, Australia; email: yongqiang.li@vu.edu.au

${ }^{3} \mathrm{PhD}$ Candidate, Victoria University, Melbourne, Australia
} 


\section{INTRODUCTION}

The majority of businesses around the world are family businesses. There is a growing interest among policy makers, business leaders and academic researchers on empirically analysing the relationship between Corporate Social Responsibility (CSR) and performance of family businesses. Family businesses have certain properties in common: they invest their own money in their business ventures at their own risks; they generally control the board; they set out the long term business agendas; and they coordinate relationships between family members and other nonfamily stakeholders (Yoshikawa et al 2014).

Consensus has yet to be reached in theoretical and empirical studies on the relationship between CSR and performance of family businesses. The relevant theories include Institutional Economics, Resource Dependency Theory, Agency Theory, Stakeholder Theory, Stewardship Theory, Utilitarian Theory and Social Emotional Wealth Theory (SEW). According to the Institutional Economics and Resource Dependency Theory, family business treats families and social relationships as very critical institutions and resources for the business. Hence the objectives for the family businesses are to optimise the SEW and social capital.

Li et al (2014) have identified three types of agency problems in a family business, namely the conflict between owners and managers, the conflict between shareholders and non-shareholding stakeholders, and the conflicts between majority shareholders and minority shareholders. The conflicts of interest between family business owners and non-family stakeholders and the conflict among members of the controlling family may give rise to a negative relationship between CSR and the performance of family businesses. The institutional environment of different countries may also have an impact on the CSR-performance relationship. The Agency Theory, however, states that the objective functions of family businesses may differ with that of non-family stakeholders, creating agency conflicts which may subsequently discount the family businesses' CSR engagement (Jain \& Jamali 2016). These theories result in discourses in explaining CSR of family businesses. Prior empirical research also leads to mixed results on the relationship between CSR and performance of family businesses (Carney \& Nason 2018; Jain \& Jamali 2016).

This paper addresses the discourse identified above by systematically reviewing the literature on the relationship between CSR and performance of family businesses. Section 2 outlines a theoretical model developed for this study and the research methodology; Section 3 reviews the relevant literature on the theoretical background and the institutional context of CSR; Section 4 summarises the literature on CSR; Section 5 summarises the literature on the relationship between CSR and performances; Section 6 concludes with a discussion of directions for future research.

\section{RESEARCH DESIGN AND METHODOLOGY}

\section{THEORETICAL MODEL FOR SYSTEMATIC REVIEW}

A systematic review of the relevant empirical researches was carried out to develop a conceptual framework for empirical research on the relationship between CSR and performance of family businesses with the help of a theoretical model (Figure 1). The research methodology of the 
systematic review was adapted from Wang et al. (2016). This review compiles the information on each segment of the model from the peer review journals obtained via the major business databases and complemented by articles from other sources such as peer reviewed journals and Google Scholar.

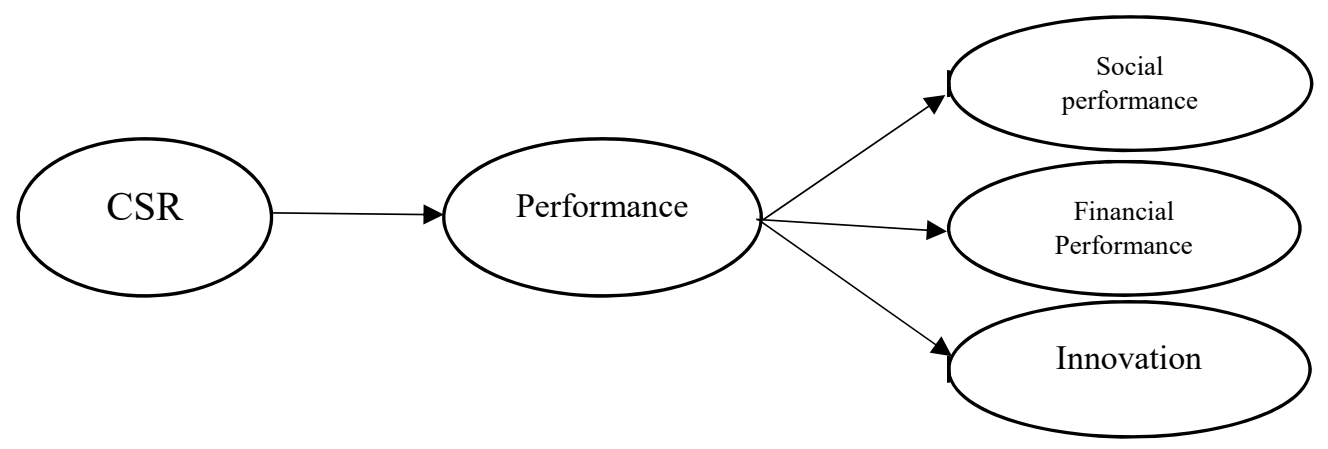

Figure 1.Conceptual Model on CSR and Performance of Family Businesses

\section{Research design and methodology}

The systematic review was undertaken by accessing the Victoria University Library business databases, namely Web of Science Core Collection (Clarivate), Scopus, EBSCO and Emerald, complemented by Google Scholar. Key words used for the searches include the combinations of "family business" AND "Performance". The selection of the articles to be included in the research was independently reviewed by the authors. The search yielded 120 articles. Further screening of the results identified forty-six articles which serve as the basis for summary of the review. Ten articles with empirical findings were used to summarise the relationship between CSR and performance.

\section{LITERATURE REVIEW}

\section{Family Businesses}

Family businesses are private entities, which are owned and managed by families (Carney \& Nason 2018). The governance problem is two-folded in family businesses - family governance, coupled with corporate governance. The ownership and control rest with family owners whose interests and objectives are different from dispersed ownership structure which had been widely explored in the main stream governance literature (Carney \& Nason 2018). Certain family members exert a more significant influence on business decisions relating to CSR than managers, shareholders, or non-family owners (Deephouse \& Jaskiewicz 2013). Family members often hold a significant number of shares in their firms, and take on management positions. Thus, the family members, regardless of whether they have any ownership or not, must be considered as an additional stakeholder in the relationship between family businesses and CSR.

The characteristics of family business are closely related to the specific objectives of owners of the family business as their interests are often focused on non-financial objectives (Marques et al 
2014). Family business research could be categorised into family ownership, family management, a combination of family ownership and management and others family members (Canavati 2018). The literature finds that ownership structure, members' strong identity within the business, SEW goal setting, family ties, long term orientation, and risk aversive attitudes, family business has a positive impact on CSR (Bingham et al. 2011). Special goal of the family business might lead to prioritisation of business interests over those of other stakeholders and may lead to the reduction of CSR levels. Family owners may also abstain from CSR engagement as a significant amount of wealth is allocated to financial performance and as CSR commitment might incur short-term costs (Bingham et al. 2011; Faller \& Knyphausen-Aufsess 2018).

\section{Stakeholders}

Stakeholders are the individuals or groups who have ownership, rights or interests in a business (Bingham 2011). In a family business, internal stakeholders include employees and investors; external stakeholders include consumers, community members and the environment. The executives of family businesses maintain a pleasant relationship with the influential members of the internal stakeholders to secure and to extend the family's control over the firm. As a result, family businesses tend not to downsize their labour force; they emphasise the importance of the quality of life; they provide more stable employment and grant more favourable employment contracts to their close family members and internal stakeholders. (Canavati 2018). The external stakeholders' relationship with groups such as customers, communities and environment groups might offer new knowledge pools which can be developed important sources of innovation (Hart \& Dowell 2011).

\section{CSR}

CSR deals with the impact of family business activities on the internal and external stakeholders that includes investors, lenders, employees, suppliers, customers, community, regulators and government (Jain \& Jamali 2016). It examines the policies and practices of the family business in relation to the policies and procedures, which are in line with social responsibilities. Businesses which engage in CSR activities adopt a broader perspective, develop closer relationships with the other stakeholders so as to identify new opportunities (Tantalo \& Priem 2016). The impact of family businesses activities on a range of stakeholders is reflected in corporate social reporting, which concerns with matters such as human rights, community involvement, environmental impact and sustainability. In addition to CSR reporting, other objectives of exercising social responsibility including education, training, work force skilling up, community engagement projects, social partnership and building harmonious relationship with consumers and community (Jain \& Jamali 2016). The comprehensive assessment of the firm's voluntary actions to improve conditions with associated stakeholder groups serves as an indicator of CSR (Bingham et al. 2011).

Measurement of CSR outcomes can be described "in terms of stakeholder engagement, philanthropic contributions, adoption of ethical codes, compliance with laws and mandates, impact assessment on stakeholders and the environment, extent of corporate social disclosures, rankings and ratings by third parties, and stock market indicators, among others" (Jain \& Jamali 2016). These various outcomes could be captured and categorised as a measure of CSR performances. The performance categories include corporate responsibility towards at several stakeholders (CR), corporate environmental performance (CEP), and the disclosures of CR and CEP, regardless of 
whether these behaviours are mandatorily or voluntarily (Jain \& Jamali 2016). Nevertheless, the business strategy and managerial choices on CSR practices and engagement are dependent on the institutional environment in which businesses operate. It is noted that "there is no standard way to measure the performance of CSR activities e.g. CSR performance, or more compactly Corporate Social Performance (CSP). Measures of CSP serve as a proxy for CSR activity by reflecting the level and extent of efforts by firms in CSR activities" (Broadstock et al. 2019). In addition, business size has a positive effect on CSR reporting in that larger firms can prepare regulatory compliance at lower cost than small and medium size businesses. Comparatively, large firms are in a position to provide more information to address how they satisfy social performances expectations of a wide range of stakeholders given their resource advantage (Coluccia et al 2018).

\section{Institutional context}

The institutional environment encompasses formal institution in the form of political, legal, and financial systems, and informal institutions such as socially valued beliefs and norms (Jain \& Jamali 2016). The regulatory stringency, anti-self-dealing index, exposure to the market for corporate control and rule-based versus relation-based are the political and legal factors considered under formal institutional environment, whereas power distance, individualism and gender gap are the factors considered socially valued beliefs and norms of the informal environment (Ioannou \& Serafeim 2012). The institutional framework embraces both formal institutions such as compulsory compliance requirements and informal institutions such as social values and expectations. Informal institutions, in the form of social values, are more finely entrenched and have a universal influence on the economies through imitative or normative adoption of practices. Whereas in contrast to informal institutions, mandatory regulations of a formal institution being in place could promote a narrow pattern of shareholder protection versus a broader pattern of stakeholder orientation (Matten \& Moon 2008).

\section{Theoretical backgrounds}

The relation between family business, CSR and performances could be formulated on the basis of multiple theoretical perspectives that includes but is not limited to Agency Theory, Stakeholder Theory, Stewardship Theory, Utilitarian Theory and SEW Theory. We will discuss each of these theories below.

\section{Agency Theory}

Agency Theory explains the relationship between principals (shareholders) and agents (managers and other corporate insiders) with divergent interests, risk tolerance, capacities, and information in business. It emphasises the board's control function and prescribes, in particular, both independence of the board from the duality of management and leadership structure (Hafsi \& Turgut 2013). Agency Theory highlights that managers might pursue their self-interest at the expense of business interests. This is mainly due to the separation of ownership and control which generates agency costs. The corporate board has the potential to reduce the agency cost and improve the financial performance of the organisation (Dobbin \& Jung 2010; Hillman \& Dalziel 2003). 
In the context of the agency framework, the board of directors is concerned with resolving problems that can exist between managers and shareholders. Independence of the board is one of the most important features of Agency Theory that enables it to function in the best interest of the shareholders and enhance monitoring the self-servicing behaviours of management. Family business owners, through the concentration of ownership, could be effective in addressing agency cost emerging from opportunistic behaviours within the business. They help to improve the agency problems with the managers and decrease the risk associated with managerial decisions on the adoption of CSR in the business (Martínez-Ferreroet al 2016).

\section{Stakeholder Theory}

The Stakeholder Theory states that a business has relationships with a broader set of stakeholders, including employees, consumers, governments, environmental advocates, and others, beyond shareholders and acts as a guide to understand the domain of a firm's responsibilities. It suggests that the firm has a contractual relationship with all stakeholders, which enable firms to be managed for the benefit of all their stakeholders in the financial as well as the nonfinancial domain (Jain \& Jamali 2016). In terms of CSR, the view of this theory has far reaching consequences in relation to the wider spectrum of managerial responsibilities in family businesses (Weber 2014).

\section{Stewardship Theory}

Grounded in psychology, sociology and leadership theories, the Stewardship Theory emphasises situational aspects of management philosophy and organisational culture (Craig \& Dibrell 2006). The executive manager, under the Stewardship Theory, is a good steward of the owners. The Stewardship Theory argues for the possible association between the principals and agents, which reflects a psychological contract. Such a close relationship with agents occurring in a communityfocused manner that directs trustworthy moral behaviours towards the firms and its shareholders (Daviset al 1997). In the family business, the ownership and management are generally not separate, as the family members themselves are the managers, or they exert enormous control over the strategic decisions of the firms. The family members are committed to the family business, and the existence of high levels of commitment among members is regarded as one of the strongest advantages and, as such, ideally, the Stewardship Theory should work well in family businesses (Subramanian 2018).

\section{Utilitarian Theory}

Utilitarian Theory proposes that businesses need to acknowledge social obligations and rights to take part in social activities. There are two categories of Utilitarian Theory school: one involves the study of social benefits and costs of the firm, and the other as functionalists which advocates for the sole function of a business - profit making. The business is seen as an investment, which should be profitable to the investors and stakeholders. From the internal perspective of the business, CSR could be considered as a defensive tactic to maintain a balance between profit making and social objectives for the economic system's equilibrium (Secchi 2007). 


\section{SEW Theory}

The SEW theory argues that common family goals such as the intention to pass on the firm to the next generation, the provision of employment to family members and social status in the community (Gomez-Mejia et al. 2011) are the essential elements to the business interests of family owners. The preservation of SEW in the decision making process is based on setting objectives other than profit maximisation. The SEW supports a positive relationship between family business owners and CSP (Canavati 2018). The justification behind the SEW approach is that the business owners have the desire to leave a legacy of business success to the future generations which are symbolised by improving relationship with stakeholders and community, by maintaining the family's reputation and by avoiding socially irresponsible practices (Deephouse \& Jaskiewicz 2013).

\section{FINDINGS}

\section{CSR}

In addition to financial performance, the family business CSR report provides ratings of CSR performance (CSP) (Bingham et al. 2011). Measures for CSP includes corporate governance, long-term commitment, social participation, and environmental protection. The corporate governance discloses the level of transparency in board information that covers information on directors, CEO, diversity policy, human rights and relationship with indigenous people. The long term commitments category includes levels of a firm's commitment to consumers, employees, and investment in R\&D. It includes product quality, product safety, antitrust, and contracting concerns. Employees related aspects include union relations, layoff policies, retirement benefits and health and safety concerns. Social participation denotes the degree to which the business has a focus on a certain social issue, and proactively uses its commitment for social change. It embraces community relationship aspects that comprise of charitable giving, support for housing, volunteer programs, investment controversies and tax disputes and also covers work/life benefits, women/ minority contracting, employment of the disabled, and non-representation of women. The environmental protection reflects the degree to which a firm has concrete goals and solid measures for environmental protection and energy-savings that include pollution prevention, clean energy, recycling, hazardous waste, climate change and regulatory problems. (Block \& Wagner 2014; Yu, Ding \& Chung 2015).

\section{Innovation}

Business needs to address the expectation of ethical behaviours from the society and consider the social and environmental impact of their operational processes as well as value adding and competitiveness for their survival. As such, it needs to be innovative to satisfy the demand for socially responsible products and services by implementing socially responsible processes across the value chain. They are to stimulate the employees to become creative in designing and developing new products and processes in collaboration with customer, supplier and business partner. Thus, innovation could be treated as performance parameters of CSR (MacGregor \& Fontrodona 2008; Rexhepiet al 2013). Empirical researches have shown that innovation resulting from the business engagement with stakeholders could enhance the financial performance of the business involved in CSR activities by product differentiation (Flammer 2015), radical process 
innovation (Dixon-Fowler et al. 2013) and as a new source of value generation (Hart \& Sharma 2004). The reputation of the businesses with CSR activities might enhance financial performance as customers are more attracted to and derive satisfaction by buying products and services from them (Luo \& Bhattacharya 2006). Various measures of the performance of business engage in CSR activities are briefly summarised in the following sections.

\section{Financial performance}

The financial performance are normally measured in accounting and financial terms (Jordan et al 1997; Bahhouth et al 2014) (Table 1).

Table 1 Financial Performance Measure

\begin{tabular}{|l|l|l|}
\hline Measure & \multicolumn{1}{|c|}{ Indicators } & \multicolumn{1}{|c|}{ Literature } \\
\hline Accounting & Return on Asset (ROA) & Jordan et al (1997) \\
& Net Income/Total Asset & Bahhouth et al (2014) \\
& Return on equity (ROE): & \\
& Net Income/Shareholders Equity & \\
& Current ratio: Current assets/current liabilities. & \\
& Debt to equity ratio: & \\
& Total debt/total equity. & \\
& Operating ratio: & \\
& Gross revenue/operating and maintenance & \\
& charges. & \\
& Cash flow coverage: & \\
\hline Financial & Cash flow/principal and interest. & Nekhili et al. (2017) \\
\hline
\end{tabular}

\section{Social Performance (ethical and environmental performance)}

Table 2 Social Performance Measure

\begin{tabular}{|l|l|l|}
\hline Measure & Indicators & Literature \\
\hline $\begin{array}{l}\text { Community } \\
\text { relations }\end{array}$ & charitable giving & $\begin{array}{l}\text { Block \& Wagner } \\
(2014)\end{array}$ \\
\hline $\begin{array}{l}\text { Diversity } \\
\text { aspects }\end{array}$ & promotion policies related to women & $\begin{array}{l}\text { Block \& Wagner } \\
(2014)\end{array}$ \\
\hline $\begin{array}{l}\text { Employee } \\
\text { relations }\end{array}$ & $\begin{array}{l}\text { Union relations } \\
\text { Strategic management processes and conducts communication programs } \\
\text { to develop and maintain effective long-term relationships between } \\
\text { management and employees. }\end{array}$ & $\begin{array}{l}\text { Block \& Wagner } \\
(2014) \\
\text { Hon et al. (1999) }\end{array}$ \\
\hline $\begin{array}{l}\text { Ecological } \\
\text { environment }\end{array}$ & $\begin{array}{l}\text { Hazardous waste } \\
\text { Greenhouse gas emissions } \\
\text { Population exposure to air pollution } \\
\text { Pollution loads to water bodies }\end{array}$ & $\begin{array}{l}\text { Block \& Wagner } \\
(2014) \\
\text { OECD(2018) }\end{array}$ \\
\hline $\begin{array}{l}\text { Product } \\
\text { aspects }\end{array}$ & $\begin{array}{l}\text { Product quality } \\
\text { Energy and material use (resources) } \\
\text { Natural environment (sinks) } \\
\text { Social justice and community development } \\
\text { Economic performance } \\
\text { Workers, } \\
\text { Types of products }\end{array}$ & $\begin{array}{l}\text { Block \& Wagner } \\
(2014) \\
\text { Veleva \& Ellenbecker } \\
(2001)\end{array}$ \\
\hline
\end{tabular}


Lv, Li \& Mitra | CSR and Performance of Family Businesses

\section{Innovation}

Table 3 Measure of Innovation

\begin{tabular}{|c|c|c|}
\hline Measure & Indicators & Literature \\
\hline $\begin{array}{l}\text { Knowledge } \\
\text { creation }\end{array}$ & $\begin{array}{l}\text { Knowledge-intensity that include increasing expenditures on } \\
\mathrm{R} \& \mathrm{D} \text { and information and computer technologies, and the } \\
\text { increasing proportions of high-tech goods. }\end{array}$ & $\begin{array}{l}\text { Dodgson \& Hinze (2000) } \\
\text { Dziallas \& Blind (2019) }\end{array}$ \\
\hline $\begin{array}{l}\text { Technological } \\
\text { strengths }\end{array}$ & The indicator used is the 'Current Impact Index (CII) & Dodgson \& Hinze (2000) \\
\hline $\begin{array}{l}\text { Time-based } \\
\text { strategies }\end{array}$ & $\begin{array}{l}\text { Technology cycle time. At the firm level, this indicator is } \\
\text { used to determine how long it takes a firm to advance their } \\
\text { own technology from prior technology. }\end{array}$ & Dodgson \& Hinze (2000) \\
\hline $\begin{array}{l}\text { Creativity and } \\
\text { Learning }\end{array}$ & R\&D expenditure. & Dodgson \& Hinze (2000) \\
\hline $\begin{array}{l}\text { Technology } \\
\text { fusion }\end{array}$ & $\begin{array}{l}\text { Data Mapping techniques based on patent and bibliometric } \\
\text { data are being used to analyse the structure and dynamic } \\
\text { development of scientific and technological developments, } \\
\text { including the growing inter-relationship or fusion of areas of } \\
\text { science and technology. }\end{array}$ & Dodgson \& Hinze (2000) \\
\hline
\end{tabular}

\section{Relationship between CSR and Performance in Family Businesses}

\section{CSR and Financial Performance}

Table 4 CSR and Financial Performance

\begin{tabular}{|l|l|l|}
\hline Measure & \multicolumn{1}{|c|}{ Indicators } & \multicolumn{1}{c|}{ Literature } \\
\hline Profitability & Relationship is positive and significant & Nekhili et al. (2017); Wang et al. (2016) \\
\hline
\end{tabular}

\section{CSR and Social Performance}

Table 5 CSR and Social Performance

\begin{tabular}{|l|l|l|}
\hline Measure & \multicolumn{1}{|c|}{ Indicators } & \multicolumn{1}{c|}{ Literature } \\
\hline Report on Governance, & Family business and CSP relationship is positive when \\
economic, operations, & Canavati (2018) \\
$\begin{array}{l}\text { consumers, employees, } \\
\text { suppliers, community and } \\
\text { environment. }\end{array}$ & $\begin{array}{l}\text { but negative when data from content analysis and } \\
\text { reputation ratings was used. }\end{array}$ & \\
\hline
\end{tabular}

\section{CSR and Innovation}

\section{Table 6 CSR and Innovation}

\begin{tabular}{|l|l|l|}
\hline Measure & \multicolumn{1}{|c|}{ Indicators } & \multicolumn{1}{|c|}{ Literature } \\
\hline $\begin{array}{l}\text { Financial } \\
\text { Performance }\end{array}$ & $\begin{array}{l}\text { Family Business have no influence on the connection between } \\
\text { innovation and social performance, whereas, environmental policies } \\
\text { are more positively related to innovation in family business }\end{array}$ & Wagner (2010) \\
\hline Value Creation & $\begin{array}{l}\text { CSR can act as effective delivery mechanism for family business } \\
\text { value generation by developing new products and processes in } \\
\text { collaboration with customers, suppliers and business partners. }\end{array}$ & $\begin{array}{l}\text { MacGregor \& } \\
\text { Fontrodona (2008) }\end{array}$ \\
\hline
\end{tabular}



Block \& Wagner (2014) measured Social Performance in five dimensions, namely community relations, diversity aspects, employee relations, ecological environment, and product aspects (Table 2). Dodgson \& Hinze (2000) and Dziallas \& Blind (2019) identified five indicators of innovation, namely knowledge creation, technological strengths, time-based strategies, creativity, learning and technology fusion (Table 3). Other literature generally identified a positive relationship between CSR and performance (Table 4-6).

\section{DISCUSSION AND FUTURE WORK}

Behaviours of the family business are influenced by both financial and non-financial goals, but the preservation of SEW is the core reference point from which decisions are made. The commitment of family business towards the prevention of the loss of SEW might lead to a decision that departs from profit maximisation behaviours which can bring suboptimal performance and greater risks (Gomez-Mejia et al. 2011). In addition, the business might be reluctant to incur risky investment such as R\&D (Patel \& Chrisman 2013). This, in turn, could lead to low-grade operational processes and outcomes, which has the potential to jeopardise the sustainability of the business. However, preservation of SEW could explain why the family businesses are less likely to commit environmental offences and are more concerned over the family's image and reputation. Thus the higher level of reputation of the family business, can bond the family members and inspire them to be more socially responsible (Deephouse \& Jaskiewicz 2013). The systematic review in this study found that there is a positive relationship between CSR and financial performance, social performance and innovation of family businesses, which supports the SEW Theory and the Stakeholder Theory.

The family business pursues to improve treatment of stakeholders as well as community relationships. Accordingly, this may avoid short-term strategies that have a detrimental effect on the firm's stakeholders and also build positive relationships with external stakeholders. However, family businesses can also be prone to principal-principal and interfamily conflicts that emerge when family owners are able to extract benefits from the firm at the expense of stakeholders with more dispersed equity holdings and less control over the business (Kallmuenzer 2015). They may engage in rent-seeking behaviours and steer the strategic management process of the firm to accomplish their own personal goals, which might bear no relationship to the continued success of the firm. Notwithstanding the theoretical arguments and empirical evidence for the negative relationship between family business and CSP, it is expected that the positive impact of family siness' concerns on reputation, legacy desire, and corporate governance advantages outweighs negative relationship between family businesses and CSP (Canavati 2018).

Future research should gather data from a single country that will help to exclude institutional differences in data associated with cross country studies as it might affect the estimation of CSRperformance relationship (Cai et al. 2016). In addition, it may be helpful to look inside the family business, and empirically investigate how the CSR decisions were made within the family business. 


\section{References}

Bahhouth, V, Maysami, R \& Gonzalez, R 2014, 'Are financial measures leading indicators to firm performance?', International Journal of Business, Accounting, \& Finance, vol. 8, no. 2, pp. 37-48.

Bingham, JB, Dyer, WG, Smith, I \& Adams, GL 2011, 'A Stakeholder Identity Orientation Approach to Corporate Social Performance in Family Firms', Journal of Business Ethics, vol. 99 , no. 4 , pp. $565-85$. https://doi.org/10.1007/s10551-010-0669-9

Block, J \& Wagner, M 2014, 'The Effect of Family Ownership on Different Dimensions of Corporate Social Responsibility: Evidence from Large US Firms', Business Strategy and the Environment, vol. 23, no. 7, pp. 475-92. https://doi.org/10.1002/bse.1798

Broadstock, DC, Matousek, R, Meyer, M \& Tzeremes, NG 2019, 'Does corporate social responsibility impact firms' innovation capacity? The indirect link between environmental \& social governance implementation and innovation performance', Journal of Business Research. https://doi.org/10.1016/j.jbusres.2019.07.014

Cai, Y, Pan, CH \& Statman, M 2016, 'Why do countries matter so much in corporate social performance?', Journal of Corporate Finance, vol. 41, pp. 591-609. https://doi.org/10.1016/j.jcorpfin.2016.09.004

Canavati, S 2018, 'Corporate social performance in family firms: a meta-analysis', Journal of Family Business Management, vol. 8, no. 3, pp. 235-73. https://doi.org/10.1108/JFBM-05-2018-0015

Carney, M \& Nason, RS 2018, 'Family Business and the 1\%', Business and Society, vol. 57, no. 6, pp. 1191-215. https://doi.org/10.1177/0007650316661165

Coluccia, D, Fontana, S \& Solimene, S 2018, 'Does institutional context affect CSR disclosure? A study on Eurostoxx 50', Sustainability (Switzerland), vol. 10, no. 8. https://doi.org/10.3390/su10082823

Craig, J \& Dibrell, C 2006, 'The natural environment, innovation, and firm performance: A comparative study', Family Business Review, vol. 19, no. 4, pp. 275-88. https://doi.org/10.1111/j.1741-6248.2006.00075.x

Davis, JH, Schoorman, FD \& Donaldson, L 1997, 'Toward a stewardship theory of management', Academy of Management Review, vol. 22, no. 1, pp. 20-47. https://doi.org/10.5465/amr.1997.9707180258 
Deephouse, DL \& Jaskiewicz, P 2013, 'Do Family Firms Have Better Reputations Than NonFamily Firms? An Integration of Socioemotional Wealth and Social Identity Theories', Journal of Management Studies, vol. 50, no. 3, pp. 337-60.

https://doi.org/10.1111/joms.12015

Dixon-Fowler, H, Slater, D, Johnson, J, Ellstrand, A \& Romi, A 2013, 'Beyond 'Does it Pay to be Green?' A Meta-Analysis of Moderators of the CEP-CFP Relationship', Journal of Business Ethics, vol. 112, no. 2, pp. 353-66. https://doi.org/10.1007/s10551-012-1268-8

Dobbin, F \& Jung, J 2010, 'Corporate Board Gender Diversity and Stock Performance: The Competence Gap or Institutional Investor Bias', North Carolina Law Review, no. Issue 3, p. 809.

Dodgson, M \& Hinze, S 2000, 'Indicators used to measure the innovation process: Defects and possible remedies', Research Evaluation, vol. 9, no. 2, pp. 101-14.

https://doi.org/10.3152/147154400781777368

Dziallas, M \& Blind, K 2019, 'Innovation indicators throughout the innovation process: An extensive literature analysis', Technovation, vol. 80-81, pp. 3-29.

https://doi.org/10.1016/j.technovation.2018.05.005

Faller, CM \& Knyphausen-Aufsess, DZ 2018, 'Does Equity Ownership Matter for Corporate Social Responsibility? A Literature Review of Theories and Recent Empirical Findings', Journal of Business Ethics, vol. 150, no. 1, pp. 15-40.

https://doi.org/10.1007/s10551-016-3122-x

Flammer, C 2015, 'Does corporate social responsibility lead to superior financial performance? A regression discontinuity approach', Management Science, vol. 61, no. 11, pp. 2549-68. https://doi.org/10.1287/mnsc.2014.2038

Gomez-Mejia, LR, Cruz, C, Berrone, P \& De Castro, J 2011, 'The bind that ties:

Socioemotional wealth preservation in family firms', The Academy of Management Annals, vol. 5, no. 1 , pp. 653-707.

https://doi.org/10.5465/19416520.2011.593320

Hafsi, T \& Turgut, G 2013, 'Boardroom diversity and its effect on social performance:

conceptualisation and empirical evidence', Journal of Business Ethics, vol. 112, no. 3, pp. 463-79.

https://doi.org/10.1007/s10551-012-1272-z

Hart, SL \& Dowell, G 2011, 'A natural-resource-based view of the firm: Fifteen years after', Journal of Management, vol. 37, no. 5, pp. 1464-79.

https://doi.org/10.1177/0149206310390219

Hart, SL \& Sharma, S 2004, 'Engaging fringe stakeholders for competitive imagination', IEEE Engineering Management Review, vol. 32, no. 3, pp. 28-41.

https://doi.org/10.1109/EMR.2004.25105 
Hillman, AJ \& Dalziel, T 2003, 'Boards of directors and firm performance: Integrating agency and resource dependence perspectives', Academy of Management Review, vol. 28, no. 3, pp. 383-96.

https://doi.org/10.5465/amr.2003.10196729

Hon, DLC, Florida, Uo, and, Grunig, DJE \& Maryland, Uo 1999, 'Guidelines for Measuring Relationships in Public Relations', Institute for Public Relations.

Ioannou, I \& Serafeim, G 2012, 'What drives corporate social performance the role of nationlevel institutions', Journal of International Business Studies, vol. 43, no. 9, pp. 834-64. https://doi.org/10.1057/jibs.2012.26

Jain, T \& Jamali, D 2016, 'Looking Inside the Black Box: The Effect of Corporate Governance on Corporate Social Responsibility', Corporate Governance-an International Review, vol. 24 , no. 3, pp. 253-73. https://doi.org/10.1111/corg.12154

Jordan, JL, Carlson, CN \& Wilson, JR 1997, 'Financial indicators measure fiscal health: Using financial ratios, the authors establish indicators that can be used to monitor a utility's financial performance', Journal / American Water Works Association, vol. 89, no. 8, pp. 3440 . https://doi.org/10.1002/j.1551-8833.1997.tb08274.x

Kallmuenzer, A 2015, Theoretical perspectives on family businesses, Edward Elgar Publishing Ltd., UK.

Li, Y., Armstrong, A. and Clarke, A., 2014. Relationships of corporate governance mechanisms and financial performance in Islamic banks: A meta-analysis. Journal of Law and Governance, 9(1). https://doi.org/10.15209/jbsge.v9i1.613

Luo, X \& Bhattacharya, CB 2006, 'Corporate Social Responsibility, Customer Satisfaction, and Market Value', Journal of Marketing, vol. 70, no. 4, pp. 1-18. https://doi.org/10.1509/jmkg.70.4.1

MacGregor, SP \& Fontrodona, J 2008, Exploring the fit between CSR and innovation, IESE Business School, paper, $<$ http://wallaby.vu.edu.au:2048/login?url=https://search.ebscohost.com/login.aspx?direct=tru $\mathrm{e} \& \mathrm{db}=$ edsrep\&AN=edsrep.p.ebg.iesewp.d.0759\&site=eds-live $>$. https://doi.org/10.2139/ssrn.1269334

Marques, P, Presas, P \& Simon, A 2014, 'The Heterogeneity of Family Firms in CSR Engagement: The Role of Values', Family Business Review, vol. 27, no. 3, pp. 206-27. https://doi.org/10.1177/0894486514539004

Martínez-Ferrero, J, García-Sánchez, IM \& Rodríguez-Ariza, L 2016, 'Corporate social responsibility as an entrenchment strategy, with a focus on the implications of family 
ownership', Journal of Cleaner Production, vol. 135, pp. 760-70.

https://doi.org/10.1016/j.jclepro.2016.06.133

Matten, D \& Moon, J 2008, "'Implicit" and "explicit" csr: a conceptual framework for a comparative understanding of corporate social responsibility', Academy of Management Review, vol. 33, no. 2, pp. 404-24.

https://doi.org/10.5465/amr.2008.31193458

Nekhili, M, Nagati, H, Chtioui, T \& Rebolledo, C 2017, 'Corporate social responsibility disclosure and market value: Family versus nonfamily firms', Journal of Business Research, vol. 77, pp. 41-52.

https://doi.org/10.1016/j.jbusres.2017.04.001

Oecd \& Ocde 2018, Oslo Manual 2018 : Guidelines for Collecting, Reporting and Using Data on Innovation, 4th Edition, Éditions OCDE / OECD Publishing.

Patel, PC \& Chrisman, JJ 2013, 'Risk abatement as a strategy for R\&D investments in family firms', Strategic Management Journal.

https://doi.org/10.1002/smj.2119

Rexhepi, G, Kurtishi, S \& Bexheti, G 2013, 'Corporate Social Responsibility (CSR) and Innovation-The Drivers of Business Growth?', Procedia - Social and Behavioral Sciences, vol. 75 , pp. 532-41.

https://doi.org/10.1016/j.sbspro.2013.04.058

Secchi, D 2007, 'Utilitarian, managerial and relational theories of corporate social responsibility', International Journal of Management Reviews, vol. 9, no. 4, pp. 347-73. https://doi.org/10.1111/j.1468-2370.2007.00215.x

Subramanian, S 2018, 'Stewardship Theory of Corporate Governance and Value System: The Case of a Family-owned Business Group in India', Indian Journal of Corporate Governance, vol. 11, no. 1, pp. 88-102.

https://doi.org/10.1177/0974686218776026

Tantalo, C \& Priem, RL 2016, 'Value creation through stakeholder synergy', Strategic Management Journal, vol. 37, no. 2, pp. 314-29.

https://doi.org/10.1002/smj.2337

Veleva, V \& Ellenbecker, M 2001, 'Indicators of sustainable production: framework and methodology', Journal of Cleaner Production, vol. 9, no. 6, pp. 519-49. https://doi.org/10.1016/S0959-6526(01)00010-5

Wagner, M 2010, 'Corporate Social Performance and Innovation with High Social Benefits: A Quantitative Analysis', Journal of Business Ethics, vol. 94, no. 4, pp. 581-94. https://doi.org/10.1007/s10551-009-0339-y

Wang, Q, Dou, J \& Jia, S 2016, 'A Meta-Analytic Review of Corporate Social Responsibility and Corporate Financial Performance: The Moderating Effect of Contextual Factors', 
Business and Society, vol. 55, no. 8, pp. 1083-121.

https://doi.org/10.1177/0007650315584317

Weber, O 2014, 'Environmental, Social and Governance Reporting in China', Business Strategy \& the Environment (John Wiley \& Sons, Inc), vol. 23, no. 5, pp. 303-17.

https://doi.org/10.1002/bse.1785

Yoshikawa, T, Zhu, H \& Wang, P 2014, 'National governance system, corporate ownership, and roles of outside directors: A corporate governance bundle perspective', Corporate Governance: An International Review, vol. 22, no. 3, pp. 252-65. https://doi.org/10.1111/corg.12050

Yu, A, Ding, HB \& Chung, HM 2015, 'Corporate social responsibility performance in family and non-family firms: The perspective of socio-emotional wealth', Asian Business \& Management, vol. 14, no. 5, pp. 383-412.

https://doi.org/10.1057/abm.2015.16 